\title{
Dialog w edukacji religijnej
}

W świecie coraz bardziej pluralistycznym dialog staje się podstawowym narzędziem poszukiwania właściwego kształtu życia społecznego, a także szukania prawdy o człowieku. Odżywanie idei dialogu, jakie mimo wszelkich złych doświadczeń i porażek stało się udziałem ludzi drugiej połowy $\mathrm{XX}$ wieku, wydaje się być nie tylko sprawą nietrwałej mody intelektualnej. Współczesny człowiek coraz natarczywiej, obok czy mimo zjawiska fundamentalizacji niektórych społeczeństw, odczuwa potrzebę autentycznego spotkania z innymi ludźmi. Procesy gwałtownej industrializacji i urbanizacji prowadzą do zjawiska psychicznego wyobcowania poszczególnych jednostek i przynoszą syndrom człowieka samotnego w thumie. Proces ten jest zwielokrotniany przez narastającą atomizację społeczeństw na tle społeczno-politycznym i ideologicznym. Ludzie żyją w różnego rodzaju grupach społecznych, które nie są wspólnotami. Samotny i anonimowy człowiek w thumie tęskni za prawdziwym dialogiem ${ }^{1}$. Nie sposób sobie także wyobrazić życia religijnego, a zwłaszcza wiary świadomej i udziału we wspólnocie religijnej, bez ducha i kultury dialogu.

Według Katechizmu Kościoła katolickiego, wiara ma charakter dialogiczny: Bóg najpierw włożył w ludzką naturę tęsknotę do siebie, znajdującą wyraz w ludzkim poszukiwaniu sensu; na to poszukiwanie Bóg odpowiada swoim Objawieniem, a zwieńczeniem całego procesu jest ludzkie przyjęcie

* Ks. prof. dr hab. Jerzy Bagrowicz jest wykładowcą na Wydziałach: Teologicznym i Nauk Pedagogicznych Uniwersytetu Mikołaja Kopernika w Toruniu, założycielem i redaktorem naukowym czasopisma „Paedagogia Christiana”.

${ }^{1}$ S. Kowalczyk, Chrześcijaństwo a dialog światopogladowy, w: M. Rusecki (red.), Zzagadnień światopogladu chrześcijańskiego, Lublin 1989, s. 189. 
Objawienia, dobrowolny akt wiary (por. KKK 142$)^{2}$. Dlatego tak ważne jest wychowanie do dialogu realizowane $\mathrm{w}$ edukacji religijnej $\mathrm{w}$ różnych środowiskach i na różnych jej poziomach. Spróbujmy - choćby częściowo - odpowiedzieć na pytania w rodzaju: Jakie są podstawy wychowania do postawy dialogu w edukacji religijnej? W czym owo wychowanie wyraża się najpełniej? Jakie wymogi przynosi pod tym względem pedagogika religijna?

\section{Podstawy teologiczne dialogu - zarys zagadnienia}

Pierwszą i ostateczną racją, fundamentem, na którym opiera się dialog w edukacji religijnej jest - jak to określił Jacek Salij - „dialogiczność” Boga Trójjedynego. Bóg w Trójcy Jedyny: Ojciec i Syn, i Duch Święty, jest wspólnotą Osób, całkowicie i bez reszty na siebie otwartych ${ }^{3}$. Ta „dialogiczność” Boga w Trójcy Jedynego jest źródłem nie tylko dialogu Boga z człowiekiem, ale także źródłem, uzasadnieniem i modelem dialogu ludzi między sobą. Dlatego też mówiąc o dialogu w edukacji religijnej, nie możemy jedynie odnosić się do pedagogiczno-dydaktycznych reguł dialogu, ale należy wskazać - choć pokrótce - na to, co na kanwie Objawienia możemy powiedzieć o podstawach dialogu edukacyjnego w tak niełatwej materii, jaką jest wychowanie człowieka do dialogu z Bogiem i innym człowiekiem.

Istotne dla zrozumienia podstaw dialogicznego charakteru edukacji religijnej są prawdy zawarte w pierwszych rozdziałach Księgi Rodzaju, szczególnie opis stworzenia człowieka. Przekazuje on podstawowe prawdy o naturze człowieka, o jego relacji do Boga i do innych ludzi. W Księdze Rodzaju mamy dwa opisy stworzenia człowieka. W pierwszym z nich znajdujemy bardzo ważne wyrażenie określające wyniesienie człowieka i jego godność: „Uczyńmy człowieka na Nasz obraz, podobnego Nam (...). Stworzył więc Bóg człowieka na swój obraz, na obraz Boży go stworzył" (Rdz 1, 26-27). Drugi opis stworzenia człowieka ukazuje, że człowiek został stworzony jako współpracownik Boga w dalszym doskonaleniu świata: „Pan Bóg wziął zatem człowieka i umieścił go w ogrodzie Eden, aby uprawiał go i doglądał" (Rdz 2, 15).

Człowiek w odróżnieniu od zwierząt otrzymuje tchnienie Boże. Jest ono źródłem nie tylko życia fizycznego, ale ukazuje pozycję człowieka pośród stworzeń. On nadaje nazwy zwierzętom i w ten sposób potwierdza swą

2 Por. Radziłem się dróg. Z Tomášem Halíkiem rozmawia Jan Jandourek, Poznań 2001, s. 117.

3 J. Salij, Dialogiczny wymiar wiary religijnej, „Paedagogia Christiana” 2/26 (2010), s. $17-18$. 
władzę nad nimi. Człowiek został stworzony na obraz i podobieństwo Boże, a to - w świetle całości Objawienia - oznacza, że tylko człowiekowi udzielił Bóg czegoś ze swego życia i swej mocy. Obraz Boży wszczepiony człowiekowi w chwili stworzenia był początkiem tej solidarności Boga z człowiekiem, która osiagnie swój szczytowy punkt w momencie wcielenia Syna Bożego ${ }^{4}$. Człowiek jest więc przedstawiony jako zdolny do dialogu z Bogiem, jest istotą wolną, która decyduje o sobie.

Historia Starego Przymierza nie jest jedynie opowiadaniem o losach kształtującego się ludu, nie jest jedynie zapisem dokumentującym prawa i obowiązki Izraela, ale jest historią szczególnego rodzaju. Jest to kronika bardzo osobistego związku Boga Jahwe z konkretną społecznością, którą jest naród izraelski.

Jednym $\mathrm{z}$ istotnych elementów dialogu człowieka z Bogiem jest Prawo Przymierza. Boże polecenia zawarte w Prawie Przymierza zostały przekazane ludowi przez Mojżesza. Lud zaś przyjął na siebie obowiązek przestrzegania tych poleceń: „Wtedy cały lud jednogłośnie powiedział: Uczynimy wszystko, co Jahwe rozkazał" (Wj 19, 8).

Zanim Bóg przekazał przez Mojżesza tablice prawa przymierza zwane często Dekalogiem, daje dowody opieki i pełnego miłości osobowego kontaktu z człowiekiem. W okresie nomadycznego życia patriarchów Bóg wędruje z nimi, prowadzi ich, opiekuje się nimi, komunikuje im swoją wolę za pośrednictwem słowa. Odpowiedzią zaś na to słowo jest zawierzenie patriarchów, którzy wierzą słowu Boga i przyjmują je, ponieważ ustawicznie doświadczają pomocy i opieki Boga ${ }^{5}$.

Stary Testament pokazuje wymownie, że stosunek do Boga był odczuwany jako stosunek osobowy. Księga Wyjścia tę osobową relację wyraża powiedzeniem: „Ja jestem Pan, Bóg twój” $(20,2)$. Zaimek dzierżawczy „twój” bardziej wymownie niż długie formuły wyraża relację wzajemnej przynależności Boga do Izraela i Izraela do Boga: Bóg Jahwe jest Bogiem, który dobrowolnie się darował, wszedł w relację ze swoim ludem i dlatego do niego należy ${ }^{6}$.

Relacja Boga z Izraelem, z poszczególnymi osobami czy też grupami osób, jest wyrażona w ponad stu miejscach Starego Testamentu za pomoca formuly „być z”. W patriarchalnych opowiadaniach o Izaaku i Jakubie „bycie z" jest obiecane jednostkom albo potwierdzone w ich przypadku jako towarzyszenie i przewodnictwo w wędrówkach. Dialog Boga z człowiekiem

${ }^{4}$ Por. M. Filipiak, Biblia o człowieku, Lublin 1979, s. 79-87.

${ }_{5}^{5}$ Por. H. Muszyński, Bóg Abrahama, Izaaka i Jakuba, Bóg Ojców naszych, „Ateneum Kapłańskie" 114 (1990), s. 6-9.

${ }^{6}$ Tamże, s. 11. 
wyraża się w bardzo różnych sytuacjach. Jest to opieka, ustawiczne towarzyszenie Ludowi w drodze: „A Pan szedł przed nimi podczas dnia jako słup obłoku, by ich prowadzić droga, podczas nocy zaś jako słup ognia, aby im świecić, żeby mogli iść we dnie i w nocy. Nie ustępował sprzed ludu słup obłoku we dnie ani słup ognia w nocy" (Wj 13, 21-22).

Wyrazem więc dialogu Boga z człowiekiem jest ciagła Jego obecność z Ludem Wybranym. Podstawowym natomiast środkiem dialogu Boga z człowiekiem jest słowo, które Bóg kieruje do ludzi. Patriarchowie i prorocy są tego świadomi, gdy nauczanie skierowane do Ludu rozpoczynają często słowami: „Tak mówi Pan”. „Ale teraz tak mówi Pan, Stworzyciel twój Jakubie, i Twórca twój, o Izraelu: «Nie lękaj się, bo cię wykupiłem, wezwałem cię po imieniu: tyś mój»” (Iz 43, 1). Słowa proroków i Patriarchów to często słowa bezpośredniej rozmowy Boga z człowiekiem: „Rzekł Pan do Mojżesza: «Idź do faraona i powiedz mu: Tak powiedział Pan, Bóg Hebrajczyków: Wypuść mój lud, aby Mi służył»" (Wj 9, 1).

Pismo święte dokumentuje nie tylko słowo Boga do człowieka, ale jest także historią rozmowy człowieka z Bogiem. Najpiękniejszym - jak się wydaje - zapisem tego dialogu człowieka z Bogiem są psalmy. Przekazują one nie tylko słowa radości i uwielbienia Boga, wiary, nadziei i miłości, ale także dramat ludzkiego serca, które przez grzech odchodzi od miłości Boga, zdradza bliźniego i w modlitwie pokutnej odnajduje drogę powrotu.

Rozmowy człowieka z Bogiem przybierają niekiedy formę zmagania się, a nawet buntu. Szczególnie w Starym Testamencie mamy wiele przykładów na to, że zmaganie z Bogiem jest bardzo autentyczną postacią spotkania Boga z człowiekiem, że Bóg kocha tych, którzy się z Nim zmagaja, słucha tych, którzy wiodą z Nim spór. Wymownym przykładem takiej sytuacji jest zmaganie się patriarchy Jakuba z Bogiem nad potokiem Jabbok (por. Rdz 32, 25-30). Ten dialog zmagania się z Bogiem przemienia Jakuba. Po tej „walce z Bogiem" do Kanaanu wchodzi rzeczywiście jako inny człowiek. Historia jego życia to historia drogi od ateizmu do wiary świadomej, osobowej rozmowy z Bogiem. Zmaganie się Jakuba z Bogiem ukazuje, jak niełatwy jest proces przemiany człowieka w jego stosunku do Boga. Bóg w tej walce z Jakubem objawia się jako ten, który daje się człowiekowi, jest w ciągłej gotowości dialogu z człowiekiem, jest bliski ludziom i pragnie im błogosławić7.

Słowo Boga stanowi podstawę naszej wiary, ponieważ również Bóg wypowiedział siebie w swoim słowie: „Wielokrotnie i na różne sposoby przemawiał niegdyś Bóg do ojców przez proroków", a następnie autor dodaje: „a w tych ostatecznych dniach przemówił do nas przez Syna” (Hbr 1, 1-2).

7 Por. J. Bagrowicz, S. Jankowski, ,, Pan, Bóg twój, wychowuje ciebie” (Pwt 8, 5). Studia z pedagogii biblijnej, Toruń 2005, s. 87-103. 
Jezus Chrystus jest słowem, które było u Boga, było Bogiem i jako Jego Słowo zamieszkało pośród ludzi (por. J 1, 14).

Ewangelia jest pełna scen ukazujących Chrystusa w rozmowie. Rozmawia On również z tymi, z którymi nikt się w rozmowę nie wdawał - z celnikami i jawnogrzesznicami, z dziećmi, z Samarytanką, z trędowatymi. Przekracza wszelkie granice. Cała Jego historia jest zarazem jedną wielką rozmową z Ojcem, rozmowa, która trwa także na pustyni i w mroku opuszczenia na krzyżu i również tam nie przestaje być pytaniem - tym najboleśniejszym pytaniem, jakie kiedykolwiek padło między niebem a ziemią: „Boże mój, Boże mój, czemuś mnie opuścił?" (Mt 27, 46)

Wydaje się, że dla podstaw dialogu człowieka z Bogiem i ludzi między sobą od strony teologicznej istotna jest tajemnica paschalna Jezusa Chrystusa, czyli jego męka, śmierć i zmartwychwstanie. Syn Boży stał się człowiekiem, podjął ofiarę cierpienia i śmierci krzyżowej jako świadectwo miłości Boga do człowieka, jako wyraz dialogu miłości Boga z człowiekiem. Zmartwychwstanie Jezusa Chrystusa jest zwieńczeniem tego zaproszenia do życia łaski, do łączności z Bogiem, które pierwszy człowiek otrzymał w darze stworzenia go na Boże podobieństwo (por. Rdz 1, 26-27).

Najpełniej natomiast podstawę relacji ludzi między sobą ukazał Jezus w Kazaniu na górze, gdy przypomniał wagę przykazania miłości. Wypełnienie tego przykazania aż do radykalizmu miłości nieprzyjaciół wskazuje na najgłębsze podstawy dialogu, który nie może być ograniczony poczuciem krzywdy, niechęcią czy nieprzyjaznymi uczuciami (por. Mt 5, 43-48).

Bogactwo dialogu Boga z człowiekiem i człowieka z Bogiem, ukazane na kartach Pisma św. Starego i Nowego Testamentu, jest istotnym elementem modelu dialogu ludzi ze sobą, a szczególnie tego dialogu, który leży u podstaw edukacji religijnej człowieka.

\section{Podstawy pedagogiczne dialogu}

Pomijamy tu dyskusję wokół istoty dialogu, jego rodzajów i aspektów. M. Navratil określa dialog jako proces, przez który dwa podmioty używają słowa w zamiarze osiagnięcia zrozumienia tego, co każdy z nich myśli i czym żyje, oraz dzięki któremu dochodzą w pewnej mierze do wzajemnego zbliżenia swoich punktów widzenia i właściwego sobie sposobu życia9. Dialog określa się też często jako życzliwe i twórcze spotkanie, inspirowane po-

${ }^{8}$ Radziłem się dróg, s. 93-94.

${ }_{9}$ M. Navratil, Dialogue, w: Vocabulaire de Psychopedagogie et de Psychiatrie de l'enfant, Paris 1963, s. 174. 
szukiwaniem pełnej prawdy i autentycznej miłości, bez których nie ma trwałego humanizmu ${ }^{10}$. W dialogu odróżnia się proces od postawy dialogu, która wyraża się gotowością zrozumienia, zbliżenia i współdziałania z innymi ${ }^{11}$.

Jest cechą charakterystyczną wszystkich dyktatur, że nie jest w nich możliwy w żadnej dziedzinie poważny dialog między ludźmi, dzięki któremu możliwe byłoby normalne współżycie międzyludzkie. Widać to na przykładzie bliskim naszemu doświadczeniu historycznemu systemów: faszystowskiego i komunistycznego. Także pedagogika uwikłała się w zależności od tych systemów. Historia przekonuje jednak, że taki ucisk i brak dialogu na dłuższą metę nie jest możliwy. Brak wolności jednostki czy też narodów prowadził i prowadzi nadal ku rewolucjom czy przewrotom, masowym eksterminacjom. I na to reaguje pedagogika, czego przykładem może być pedagogika wyzwolenia Paulo Freiere w Ameryce Południowej. Wyzwolenie ludzi nie musi się dokonywać zawsze w sposób krwawy. Najnowsza historia, szczególnie ta w Europie Środkowo-Wschodniej jest tego dobrym przykładem. Wyzwolenie może być także owocem dialogu między ludźmi i dzięki wychowaniu człowieka w dialogu międzyludzkim. Kto taki dialog zapoczątkowuje, ten inicjuje myślenie i działanie humanistyczne.

Trzeba jednak zauważyć, że zagrożenia dla wychowania humanistycznego mogą istnieć także w systemach demokratycznych i w wolnym wychowaniu człowieka. Theodor Litt już dawno wskazał, że umożliwić rozwój, wzrost można przede wszystkim przez pomoc wychowawczą ${ }^{12}$. Sam wzrost pozostawiony na dziko może być jednak niekontrolowany, a z drugiej strony przewodnictwo w tym rozwoju narzucane niejako z góry może także zburzyć wolność osobista jednostki. Pedagogika dialogu zna oba te niebezpieczeństwa i ukazuje, że dialog zawsze polega na dwu elementach: słowie i odpowiedzi „tak” ze strony jednego, jak i drugiego uczestnika dialogu. Słowo i odpowiedź są podstawowe dla dialogicznego uczenia się i nauczania ${ }^{13}$.

Dialog jest takim spotkaniem, które dla procesu wychowawczego ma istotne znaczenie. Spotkać to coś więcej niż mieć świadomość, że Inny jest obecny obok mnie. Spotkać to wykraczać poza siebie, to doświadczać Innego. Spotkanie osobowe jest wydarzeniem i pociąga za sobą zmianę ob-

${ }^{10}$ Por. S. Kowalczyk, Z problematyki dialogu chrześcijańsko-marksistowskiego, Warszawa 1977, s. 33.

${ }^{11}$ Por. J. Tarnowski, O użyteczności niektórych kategorii personalistycznych dla pedagogiki, „Kultura i Edukacja” 2 (1993), s. 29-33.

${ }_{12}$ Por. E. J. Birkenbeil, Erziehung zur Dialogfähigkeit. Die aus christlicher Sicht zu verantwortende Erziehung in einer pluralen-interkulturalen Welt, w: W. Scharl, T. Pöggeler (Hrgs), Gegenwart und Zukunft christlicher Erziehung, Würzburg 1994, s. 226-228.

13 J. Bagrowicz, Towarzyszyć wzrastaniu. Z dyskusji o metodach i środkach edukacji religijnej młodzieży, Toruń 2006, s. 238-239. 
cowań. G. Koć-Seniuch za Lévinasem podkreśla, że spotkanie dialogowe „twarzą w twarz” jest sposobem uobecniania wartości najwyższych. W ten sposób dialog zamyka w sobie najgłębszy sens wychowania. Jest on bowiem tą przestrzenią edukacji i wychowania, w której dokonuje się proces stawania się poprzez relację człowiek-człowiek, poprzez wspólne poszukiwanie wartości najwyższej - godności osoby ludzkiej ${ }^{14}$. Pedagogika chrześcijańska podkreśla, że ostatecznym źródłem i fundamentem godności człowieka jest akt stwórczy Boga, który stwarzając człowieka czyni go „na obraz Boży”, nadaje mu niemal sakralną godność. Racją tej godności nie jest religia wyznawana przez człowieka, ani jego stan, ale samo człowieczeństwo. Nie można zredukować człowieka do roli przedmiotu, ponieważ Bóg go tak ukształtował, iż nosi on w sobie ,znamię” Boga samego. Bóg uczynił człowieka istotą wolną, osobą zdolną do dialogu z Bogiem i innymi ludźmi ${ }^{15}$.

Spotkania w dialogu wychowawczym niosą możliwości rozwoju osobowego zarówno ucznia, jak i nauczyciela. Mogą być one realizowane w różnych sytuacjach i uwarunkowaniach. Ważne, aby realizowały one podstawowe idee wychowawcze i cele edukacji we współczesnym społeczeństwie.

Pedagogika dialogu promuje trzy podstawowe idee, ważne dla wychowania postawy dialogu:

1. Przez demokratyzację pragnie otworzyć ludziom szansę kształtowania właściwego światopoglądu i życia w społeczeństwie pluralistycznym;

2. Dąży do tego, aby dzięki dialogowi nie narzucać innym światopoglądu, ale wychować do tolerancji;

3. Prowadzi do działań dla stworzenia społeczeństwa braterskiego z intencją, aby świat był przestrzenią myślenia i życia ${ }^{16}$.

Należy z mocą podkreślić, że dialog może być realizowany jedynie przez jednostki świadome swej tożsamości. Dlatego też warto pamiętać o tym, że wychowanie do dialogu oznacza podjęcie wysiłków w tym kierunku. Jeśli człowiek ma odnaleźć się i ostać w demokratycznym i pluralistycznym społeczeństwie, gdzie funkcjonują różne światopoglądy, potrzebuje wzmocnienia tożsamości. Bez posiadania własnego punktu oparcia będzie jedynie igraszką różnych modnych trendów. Potrzeba tej świadomości własnej tożsamości jest szczególnie istotna w wychowaniu do dialogu człowieka z Bogiem, a jest to przecież jeden z istotnych celów edukacji religijnej.

${ }_{14}$ Por. G. Koć-Seniuch, Dialog, w: T. Pilch (red.), Encyklopedia pedagogiczna XXI wieku, t. I, Warszawa 2003, s. 690.

15 Por. J. Bagrowicz, Stawać się bardziej człowiekiem. Z podstaw edukacji religijnej, Toruń 2008, s. 53-54.

${ }^{16}$ Tenże, Towarzyszyć wzrastaniu, s. 238-239. 


\section{Wychowanie do dialogu czlowieka z Bogiem}

Najwspanialszym wyrazem dialogu człowieka z Bogiem jest modlitwa oraz życie religijne praktykowane w osobowej relacji człowieka z Bogiem i we wspólnocie. Aby dialog w edukacji religijnej mógł w ogóle zaistnieć, potrzebna jest jego obecność we wspólnotach podstawowych, w których człowiek dorasta, jest kształtowany, zwłaszcza pod względem religijnym, dojrzewając do dialogu z Bogiem i ludźmi.

\section{Dialog $w$ rodzinie - u podstaw dialogu $w$ rozwoju religijnym czlowieka}

Człowiek przychodzi na świat jako dar Boży, jako owoc miłości dwojga ludzi, dialogu pośredniczenia w przekazie życia, którego Panem jest Bóg. Radość z narodzin dziecka $\mathrm{w}$ rodzinie jest tego dialogicznego charakteru miłości małżeńskiej najpiękniejszym wyrazem. Rodzice oczekują z niecierpliwością pierwszego uśmiechu dziecka, bo to pierwsza odpowiedź dziecka na miłość, którą zostało obdarowane. Miłość rodziców jest pierwszym sygnałem dla dziecka, że jest akceptowane, że może czuć się bezpieczne. Jest ta miłość niezbędnym fundamentem rozwoju dziecka, pokarmem w prawidłowym jego dorastaniu i kształtowaniu się w nim gotowości otwarcia na miłość rodziców i tych, którzy są blisko dziecka. Jeżeli braknie tego fundamentu i pokarmu, dziecko nie będzie zdolne odkryć miłości Boga, nie będzie także zdolne do przyjęcia miłości i obdarowania nią innych.

Niezwykle ważny jest naturalny fundament wychowania do dialogu. To duch dialogu w domu rodzinnym, łaska zwykłej, pogodnej, naznaczonej miłością rozmowy członków rodziny, szacunek dla dzieci w tej rozmowie. Środowisko rodzinne jest najlepszą szkołą wychowania do rozmowy na trudne tematy, umiejętności przebaczenia, odnajdywania dróg wyjścia w trudnych sporach i nieporozumieniach.

Środowisko rodzinne jest także podstawową drogą kształcenia umiejętności dialogu człowieka z Bogiem. Podstawą tej umiejętności i najlepszą droga jej kształtowania może być modlitwa, zwłaszcza praktykowana jako wspólna modlitwa całej rodziny. Ważne, aby w wychowaniu dziecka do modlitwy, i to od wczesnego dzieciństwa, dominowała umiejętność modlitwy spontanicznej, formułowanej własnymi słowami dziecka. Nie znaczy to, aby zaniechać nauczania podstawowych formuł modlitewnych, bo to przecież modlitwa Kościoła, ale należy zadbać o to, aby nie była to jedyna forma modlitwy dziecka. Jest pod tym względem ciągle wiele zaniedbań i zdarza się, 
że dopiero dorastające dziecko w środowisku innym niż rodzinne dowiaduje się, że do Boga można mówić zwykłymi, własnymi słowami, rozmawiać z Nim tak, jak się rozmawia z kimś bliskim i przyjaznym.

W dziele wychowania do dialogu człowieka z Bogiem niezwykle istotne jest przekazanie dziecku właściwego obrazu Boga. Ważne będzie tu doświadczenie miłości ojca w rodzinie, jego przyjaznego kontaktu z dziećmi. Jeśli ojciec będzie kimś niezwykle surowym, niedostępnym dziecku, trudno będzie przekazać dziecku obraz Boga jako dobrego ojca, który kocha każdego człowieka tak, jak ojciec rodziny kocha swoje dzieci. Ciagle jednak pokutuje w wychowaniu obraz Boga jako surowego sędziego, którego należy się przede wszystkim bać; stąd blisko do religijności podszytej strachem, niechęci do modlitwy, która zamiast rozmowy pełnej zaufania i radości może się jawić jako przykry i nużący obowiązek.

Dialog w rodzinie, atmosfera zaufania i przyjaznej rozmowy dzieci z rodzicami i innymi członkami rodziny, stwarza tak bardzo potrzebny klimat zaufania, gdy dorastające dzieci przeżywają radości i kłopoty związane z dorastaniem, rozwojem uczuciowym, budzeniem się zainteresowania seksualnością. Mogą one wtedy otrzymać wsparcie, które pomoże im uniknąć bardzo trudnych doświadczeń i ochroni przed zgubną pseudoinicjacją w dorosłe życie.

\section{Dialog w nauczaniu religijnym i katechezie. Aspekty pedagogiczno-dydaktyczne}

Zarysowane wyżej uwarunkowania wychowania do dialogu religijnego powinny być tu uzupełnione wskazaniem na znaczenie poziomu dialogu edukacyjnego we współczesnej szkole. Nauczanie religijne jest przecież w Polsce od niemal dwudziestu lat ponownie w ramach szkolnej edukacji i jego charakter w dużym stopniu jest kształtowany przez to, co od strony edukacyjnej dzieje się w murach szkoły. Nauczanie religijne jest przecież częścią szkolnej dydaktyki. Jeżeli szkoła stwarza płaszczyznę dialogu opartego o partnerstwo, ma szansę stwarzać środowisko aktywności uczniów, przejawiającej się $\mathrm{w}$ aktywnej współpracy w procesie przekazu wiedzy. Przewaga monologu nauczyciela będzie natomiast rodzić postawę bierności, gasić inicjatywy uczniów, zniechęcać do samodzielności myślenia i aktywnej postawy w życiu społecznym ${ }^{17}$.

17 Por. M. Śnieżyński, Dialog wnauczaniu, w: S. Kulpaczyński (red.), Dialog w katechezie, Lublin 1998, s. 43-45. 
Należy przyznać, że w wielu przypadkach dobry poziom szkolnej dydaktyki mobilizuje nauczycieli religii do podnoszenia kwalifikacji dydaktycznych. Pomaga to pokonać niezbyt dobrą tradycję metodycznej monotonii katechezy, tak typową dla wielu środowisk katechetycznego nauczania w przeszłości. W wielu środowiskach, głównie dzięki systematycznemu pogłębianiu kompetencji dydaktycznych nauczycieli religii i katechetów, dzięki dobrze prowadzonym warsztatom metodycznym, znacznie podniósł się poziom religijnego nauczania w szkole i katechezie parafialnej.

Gdy chcemy mówić o dialogu w edukacji religijnej, należy sobie najpierw przypomnieć, jak współcześnie widzi się istotę i cel nauczania religijnego. Nie straciły na aktualności słowa Jana Pawła II z adhortacji o katechizacji w naszych czasach Catechesi tradendae:

Specyficznym $[\ldots]$ celem katechezy $[\ldots]$ jest rozwinięcie z pomocą Bożą wiary dotąd początkowej, doprowadzenie do pełni i codzienne zasilanie życia chrześcijańskiego wiernych każdego wieku. [...] w całym procesie ewangelizacji katecheza ma być etapem wprowadzania i dojrzewania, to znaczy czasem, w którym chrześcijanin, przyjąwszy przez wiarę Jezusa Chrystusa, jako jedynego Pana, i przylgnąwszy do Niego całkowicie przez szczere nawrócenie serca, stara się lepiej poznać tego Jezusa, któremu się powierzył [...] (nr 20).

Lektura tekstu adhortacji pokazuje jej rodowód, zakorzenienie w kerygmatycznym charakterze przekazu katechetycznego, z podkreśleniem nie tylko aspektu dydaktycznego czy wychowawczego katechezy, ale i jej roli wtajemniczającej w wiarę i Kościół. Wiemy, że we współczesnych uwarunkowaniach nie wszystkie z tych wymiarów katechezy mogą być osiagane w szkolnej lekcji religii, nawet jeśli nazywamy ją katechezą szkolną. Dlatego może warto przypomnieć zdania $\mathrm{z}$ innego dokumentu katechetycznego, a mianowicie z Dyrektorium ogólnego o katechizacji, który uwzględniając zmieniające się uwarunkowania katechezy oraz różne kategorie uczęszczających na szkolne lekcje religii, nieco szerzej wskazuje na podstawowe jej cele:

Nauczanie religii w szkole pomaga uczniom wierzącym w lepszym zrozumieniu orędzia chrześcijańskiego w odniesieniu do wielkich problemów wspólnych religiom i charakterystycznych dla każdej istoty ludzkiej, w odniesieniu do wizji życia rozpowszechnionej w kulturze i głównych problemów moralnych, z jakimi boryka się dzisiaj ludzkość. Uczniowie, którzy poszukują lub doświadczają wątpliwości religijnych, będą mogli odkryć w nauczaniu religii w szkole, czym właściwie jest wiara w Jezusa Chrystusa, jakie są odpowiedzi, jakich Kościół udziela na ich pytania, i skorzystają z okazji lepszego przeanalizowania własnej 
decyzji. Jeśli uczniowie są niewierzący, nauczanie religii w szkole nabiera cech misyjnego głoszenia Ewangelii, czyli prowadzenia do wiary, do której wzrostu i dojrzałości będzie potem ze swej strony prowadzić katecheza w kontekście wspólnotowym (nr 75).

Współczesność przynosi więc bardziej integralne widzenie natury nauczania religijnego i jego celów. Potrzeba odkrywania sensu życia i humanizującej roli wiary w edukacji religijnej nie przekreśla realizacji jej celów, nakreślonych w adhortacji Jana Pawła II. Integralne widzenie celu formacji religijnej młodych wiąże teologiczną wizję celu ludzkiego życia z rozwojem osobowym. Podkreśla to jeszcze wyraźniej potrzebę zwrócenia uwagi na dialogiczny charakter edukacji religijnej.

Zarówno ujęcie istoty i celu katechezy prezentowane przez adhortację, jak i jej bardziej integralna wizja domagają się dialogu w edukacji. Wynika to najpierw - jak to już wskazaliśmy wyżej - z dialogicznego charakteru objawienia się Boga w Jezusie Chrystusie i dialogicznego charakteru wiary religijnej.

W tworzeniu atmosfery dialogu w edukacji religijnej wiele zależy od nauczyciela-wychowawcy. Nauczyciel religii-katecheta powinien starać się stworzyć atmosferę kreatywności i kontaktu wszystkich uczestników procesu dydaktycznego. Zdaniem J. Maritaina, w wychowaniu najważniejszą sprawą jest rozbudzenie wewnętrznych zasobów oraz kreatywnej postawy wychowanka. Wychowanie wymaga w ten sposób ze strony nauczyciela intelektualnej sympatii i intuicji, stałej troski o problemy i trudności, z którymi młodzież zmaga się, nie mogąc ich wyrazić. Nie ma na to chwytów pedagogicznych ani przepisów technicznych. Może to być tylko osobista uwaga skupiona na wewnętrznym rozkwicie rozumnej natury i wielka troska o skonfrontowanie rozkwitającego rozumu ze spójnym i dobrze usytuowanym systemem poznania. Może to być realne jedynie wtedy, gdy stworzy się klimat wzajemnego słuchania. Nie da się mówić o trosce o prawdę bez woli słuchania, bez otwarcia się na wymianę z drugimi. Szukać prawdy i odrzucić dialog - to dwie sprzeczne rzeczy. Otwarcie się na prawdę zawsze oznacza otwarcie się na dialog. Wzajemne słuchanie, rozmowa, zakłada, że każdy uczestnik spotkania może wyrazić swoje pragnienia i odczucia. Tylko w takiej atmosferze można mówić o kreatywności uczestników spotkania. Ważny jest tu autorytet nauczającego, który wie, czego chce. Jednocześnie szanuje tych, których prowadzi. Nie będzie właściwego kontaktu, ani nie wzbudzi się postawy kreatywnej u młodzieży w sytuacji, gdy prowadzący w sposób autorytarny przesądza o każdej sprawie. Pedagogika mówi tu o właściwej proporcji w poczuciu pewności siebie u nauczyciela: nadmierna pewność 
siebie u nauczyciela przytłacza uczniów, nie zachęca do współdziałania; brak tego poczucia sprawia, że traci on autorytet ${ }^{18}$.

Wychowawczo ważnym czynnikiem jest umiejętność stawiania przed uczestnikami nowych zadań i pobudzenie motywacji dla szukania rozwiązań i odpowiedzi ${ }^{19}$. Byłoby błędem, gdyby nauczyciel religii chciał wszystko młodym ułatwić i podać gotowe rozwiązania. Takie postępowanie prowadzi do nudy i obojętności wobec przekazywanych treści. Ważne, aby katecheta umiał zaprosić uczniów do wspólnego szukania odpowiedzi na trudne pytania. Dobry katecheta każdą postawioną trudność przedstawia jako wspólny problem, zadanie do rozwiązania dla wszystkich. Następnie razem ze wszystkimi przeżywa radość ze znalezienia odpowiedzi na pytanie czy trudność. On powinien służyć pomocą w dochodzeniu do prawdy. Młodzi powinni odczuć, że na katechezie uczą się rzeczy nowych, że są pobudzani do coraz bardziej dojrzałej i samodzielnej refleksji na tematy religijne. Nauczyciel religii-katecheta może i powinien pobudzić grupę do aktywności przez stawianie pytań, wątpliwości i zachęcanie do myślenia. Warto tu jednak przytoczyć zdanie św. Tomasza z Akwinu, który ostrzegał nauczycieli: „Nie kopcie rowu, który zaniedbacie zasypać”. Wiedział bowiem, że wywołanie wątpliwości, większe zamiłowanie do szukania niż do znajdowania oraz stawianie problemów, których nigdy nie da się rozwiązać - to wielcy wrogowie wychowania ${ }^{20}$.

Proces wychowania będzie łatwiejszy, gdy nauczyciel religii będzie znał zasady metodyki nauczania i wychowania uczniów na każdym poziomie ich rozwoju ${ }^{21}$, gdy będzie stosował urozmaicone metody, wystrzegał się monotonii przekazu. Powinien więc postawić głównie na metody aktywne, ale i takie, w których, gdy trzeba, odwoła się do słowa. Jedni bowiem uczniowie wolą aktywność ruchową, pracę w grupach, inni zajęcia indywidualne, jeszcze inni raczej spokojną refleksję. Różne powinny być także pomoce, którymi się posługuje. To zróżnicowanie metod pracy z uczestnikami nauczania religijnego pomoże im w odnalezieniu swego miejsca w grupie i sposobu pracy, który najbardziej im odpowiada.

Joseph Colomb, w podręcznikach i bogatej publicystyce pedagogicznoreligijnej, zwracał uwagę na dialogiczność przekazu katechetycznego. Kate-

18 J. Bagrowicz, Towarzyszyć wzrastaniu, s. 137-138.

19 Por. A. Bauman, Aktywizowanie uczenia sie jako obiecujaca perspektywa w myśleniu nauczycieli, „Problemy wczesnej edukacji” 1 (2005), s. 21-30.

20 J. Maritain, Dynamika wychowania, ,Znak” 43 (1991), s. 24.

${ }^{21}$ Por. np. J. Półturzycki, Dydaktyka dla nauczycieli, Torun 1996; S. Nalaskowski, Metody nauczania, Torun 1997; G. Hilger, Wie Religionsunterricht gestalten? - Methodenfragen, w: G. Hilger, S. Leimgruber, H-G. Ziebertz (red.), Religionsdidaktik. Ein Leitfaden für Studium, Ausbildung und Beruf, München 2001, s. 201-218. 
chezę, która posługuje się w większości przekazem nauczyciela, nazywał katechezą magisterialną, tzn. polegająca głównie na aktywności nauczających, nauczaniem niejako „odgórnym”, „mentorskim”.

Temu modelowi przeciwstawia model dialogicznej edukacji religijnej. Nie odrzucając metod opartych na słowie i form podających, wskazywał na podstawowe uwarunkowania katechezy dialogicznej. Jego zdaniem, wiele zależy od tego, czy uda się stworzyć w klasie czy grupie wychowawczej atmosferę dialogu i współpracy. Najlepsze wyniki osiaga się w takim zespole, który stanowi wspólnotę. Socjogram klasy szkolnej, w której dominuje przekaz słowny nauczyciela, właśnie jego osobę stawia w centrum; jedyny rodzaj aktywności w tym modelu nauczania zachodzi w kontakcie słownym nauczyciela z uczniami. Przekaz dialogiczny w czasie lekcji stawia na współpracę nauczyciela z uczniami i uczniów ze sobą, zarówno w pracy zespołowej, jak i indywidualnej. Socjogram klasy szkolnej czy grupy katechetycznej w dialogicznym modelu nauczania w centrum umieszcza Prawdę. Ona sprawia jedność grupy: jedność nauczyciela i uczniów poszukujących Prawdy. Nauczyciel jest tu przewodnikiem i pośrednikiem w poszukiwaniu i dojściu do Prawdy. Jest jednocześnie pierwszym w tej grupie, który stoi w służbie Prawdy. Łączy go z klasą szkolną czy grupą katechetyczną wspólnota w szukaniu i dochodzeniu do Prawdy ${ }^{22}$.

Joseph Colomb zwraca uwagę na bardzo ważny aspekt dialogicznej edukacji, a mianowicie na proces socjalizacji. Nauczyciel czy wychowawca ma szansę zadbać o to, aby w procesie socjalizacji wykorzystać tych, którzy przez swoją aktywność mogą pomóc w tym procesie. Zadaniem nauczyciela będzie animować grupę, być pedagogiem, który przeprowadzi ją poprzez kryzysy, sytuacje krytyczne, napięcia, które są nieuniknione ${ }^{23}$. Jest to istotne w procesie religijnej socjalizacji, zwłaszcza współcześnie w sytuacji społeczeństwa pluralistycznego i podlegającego procesom laicyzacji. Proces socjalizacji religijnej doznaje w tych warunkach poważnego zakłócenia, szczególnie socjalizacji religijnej w rodzinie, dlatego tym ważniejsza staje się atmosfera dialogu religijnego w grupie rówieśniczej. Wiara młodych doznaje umocnienia w atmosferze dialogu, buduje się tak ważne poczucie własnej tożsamości.

Dialogiczna edukacja religijna ma szansę spełnić dziś ważną rolę w wychowaniu do samodzielnego osądu rzeczywistości i odpowiedzialnego wyboru. Jest to szczególnie potrzebne, gdy rodzi się poważne zagrożenie dla

22 Por. J. Colomb, Le service de L'Evangile, Manuel catéchétique, II, Paris 1968, s. 142. J. Bagrowicz, Uwarunkowania skuteczności katechezy. Studium pastoralno-katechetyczne w oparciu o dorobek Josepha Colomb, Włocławek 1993, s. 94-98.

23 J. Colomb, dz. cyt., s. 145. 
dzieci i młodzieży przez różnego rodzaju uzależnienia, jak: narkotyki, alkoholizm, nikotynizm, uzależnienie od Internetu itp. Młodzi często ulegają presji środowiska, panującej modzie, promocji substancji uzależniających obecnej w mediach. Wychowanie do samodzielnego, wolnego i odpowiedzialnego wyboru staje się jednym z istotnych zadań edukacji religijnej. Zadanie to może być wypełnione wtedy, gdy edukacja ta będzie aktywizowała jej uczestników, gdy będzie budowała ich światopoglądową i osobową tożsamość.

Dialogiczna edukacja religijna może być pomocą w odnajdywaniu sensu życia. Religia i edukacja stoją w służbie tego samego procesu, w którym człowiek znajduje drogę do sensu samego siebie i sensu świata. Poszukiwanie sensu egzystencji jest zawsze koniecznym warunkiem pełni ludzkiego życia i dlatego można postawić tezę, że nie może istnieć edukacja bez religii i religia bez edukacji ${ }^{24}$. Zrealizowanie celów nauczania w nowoczesnym kształceniu nie może być osiagnięte przy ograniczeniu się jedynie do wiedzy fachowej i metodycznych sprawności. Wymaga ono również ukierunkowania na odpowiedzialność podmiotu względem własnych wiadomości i umiejętności, wyrażających się w postawie i działaniu. W tym względzie nauczanie religii może odegrać bardzo istotną rolę. Szkoła bowiem powinna pomóc młodym ludziom w poszukiwania własnej tożsamości i stawaniu się coraz bardziej człowiekiem. W kontekście ludzkiej egzystencji jest to umiejętność odpowiedzi na pytania: skąd?, dokąd? i dlaczego? konfrontowanych pod względem religijnym. Nauczanie religii jest bowiem antropologicznym zadaniem tworzenia sensu, propozycją konkretnej odpowiedzi konfrontowanej z życiową sytuacją katechizowanych ${ }^{25}$. W tym sensie religia jest sprzymierzeńcem edukacji ${ }^{26}$. Czy zawsze jednak w konkretnych uwarunkowaniach może to zadanie wypełnić? Jest wiele dowodów na to, że jej się to udaje, ale też i wiele okazji, aby powiedzieć, że są tu jeszcze spore rezerwy do wykorzystania i może za mało pomocy wychowawczej otrzymuje szkoła od tych, którzy w niej katechizują. Odkrywanie sensu, tak ważne w okresie dorastania, może znaleźć pomoc w edukacji religijnej pod warunkiem, że młodzi odnajdują w niej możliwość stawiania pytań, poszukiwania, a nawet niepokornego nonkonformizmu, czyli otwarcia wspólnoty nauczających i nauczanych na dialog i poszukiwanie.

${ }^{24}$ Por. J. Michalski, Edukacja i religia jako źródła rozwoju egzystencjalno-kognitywnego. Studium hermeneutyczno-krytyczne, Toruń 2004, s. 149-182.

${ }^{25}$ Por. tamże, s. 185-197.

${ }^{26}$ Por. B. Milerski, Religia a szkoła. Status edukacji religijnej w szkole w ujęciu ewangelickim, Warszawa 1998. 
Szkolna lekcja religii i katecheza parafialna mogą więc ułatwiać inicjację w chrześcijaństwo, zwłaszcza wtedy, gdy realizują misję wychowawczą wynikającą z głoszonego przesłania Ewangelii, gdy stwarzają przestrzeń rozmowy, aktywności, szacunku dla poszukiwań.

Realizacja tych celów i zadań powinna być wpisana w przemyślany plan wychowawczy realizowany w szkolnej katechezie. Nie wolno zapomnieć o znaczeniu wychowawczym tej pedagogii, która choć nieplanowana, raczej ukryta, wynika z postawy nauczyciela religii, więzi wychowawczej z młodzieżą, poziomu życia religijnego wspólnoty parafialnej itp. ${ }^{27}$

Edukacja religijna w duchu dialogicznym powinna liczyć się także z pewnymi uwarunkowaniami dobrze rozumianej postawy dialogu. Dialog nie może zastąpić, ani tym bardziej eliminować, ewangelizacyjnej i misyjnej postawy chrześcijan. Uszanowanie partnerów dialogu religijnego nie może prowadzić do rezygnacji z własnej tożsamości religijnej, ale do współpracy w różnych dziedzinach życia społecznego, zwłaszcza modlitwy i wspólnoty czynienia dobra. To ważny element edukacji religijnej do dialogu.

\section{Dialog we wspólnocie Kościoła wsparciem dla dialogicznej edukacji}

Od początku chrześcijaństwa przywiązywano wielką wagę do roli katechumenatu społecznego. To wspólnota wierzących pełniła wtedy rolę środowiska wychowującego i przygotowującego do życia w pogańskim świecie. We wspólnocie wierzących katechumen, czyli kandydat do chrztu, otrzymywał nie tylko pouczenie, ale przez przykład, wiarę i modlitwę wspólnoty kształtowała się jego postawa.

Wspomnieliśmy wyżej, jak ważną rolę w wychowaniu do postawy dialogicznej w wierze odgrywa katechumenat rodziny. Dramatem naszych czasów jest postępująca dechrystianizacja, tak widoczna w jednoczącej się Europie. Rodzina, która jest cząstką społeczności, w coraz mniejszym stopniu pełni rolę środowiska katechumenalnego. Tylko w małym stopniu rolę tę wypełnia środowisko szkolnej katechezy. Młodzież wchodzi w grupę społeczną, rówieśniczą czy zawodową, która jest często obojętna wobec wiary religijnej i Kościoła.

W tej sytuacji wzrasta - jak się wydaje - rola katechumenatu wspólnot religijnych, formalnych i nieformalnych. Ciagle taką wspólnotą katechumenalną może być środowisko Kościoła lokalnego, pod warunkiem, że jest to środowisko aktywności wierzących, a nie tylko osób duchownych. I jeszcze

${ }^{27}$ Por. J. Bagrowicz, Towarzyszyć wzrastaniu, s. 125-126. 
jeden ważny warunek - aby to było środowisko szanujące podmiotowość wszystkich jego członków, przyznające im prawo do aktywności wynikającej z ich misji i roli, jaką mają do spełnienia. Środowisko to ma szansę promowania autentycznego dialogu. Jeśli rolę tę wypełnia, może stanowić poważne wsparcie dla dialogicznej edukacji religijnej.

Młodzi ludzie częściej jednak niż w strukturach formalnych Kościoła odnajdują miejsce dialogu i aktywności w ruchach i wspólnotach religijnych. Czynią to tym chętniej, gdy środowisko na przykład parafii nie potrafiło „zagospodarować" ich potrzeby bycia razem, stworzenia przestrzeni swobodnej rozmowy, wspólnoty modlitwy, działania i aktywności nie tylko czysto religijnej. Zaspokojenie tej naturalnej potrzeby identyfikacji z grupą rówieśniczą może być doskonałą okazją realizacji rozwoju religijno-moralnego. Młodość jest okresem, w którym młodzi niejednokrotnie zrywają z praktykami religijnymi. Nie odpowiada im tradycyjne środowisko wspólnot parafialnych, gdzie liturgia i sposób funkcjonowania wspólnoty są nastawione na potrzeby ogółu wiernych i gdzie mało jest możliwości aktywności dostosowanej do młodzieży. Przeżywanie tej aktywności w małej grupie pozwała młodym na pogłębienie więzi także z Kościołem instytucjonalnym. Dokonuje się proces przechodzenia od wiary przejętej niejako „dziedzicznie” w rodzinie do wiary bardziej świadomej, do podejmowania decyzji w oparciu o wiarę osobistą $^{28}$. Dochodzenie do wiary dojrzałej, osobistej, może się realizować jedynie przez edukację religijna, która praktykuje dialog nie tylko jako zabieg dydaktyczny, ale stwarza naturalną przestrzeń dialogu, atmosferę akceptacji młodego człowieka, otwarcia nie tylko na jego sukcesy, ale i dramaty, których dziś nie brakuje.

Znakomitym podglebiem dla realizacji dialogu w edukacji religijnej staje się dziś dialog chrześcijaństwa z innymi religiami i dialog ekumeniczny chrześcijan. Rozwój Kościoła starożytnego i średniowiecznego był możliwy także dzięki temu, że teologia Kościoła tamtej epoki podjęła dialog z greckimi filozofami - Platonem, Arystotelesem, stoikami itp. Współczesny Kościół podejmuje dialog z innymi religiami, postrzegając je - jak mówi T. Halik jako systemy myślowe, a nie ośrodki kultu fałszywych bogów. Inne religie mogą być katalizatorem rozwoju chrześcijaństwa. Gdyby bowiem w pierwszych wiekach przeważył u chrześcijan lęk przed życzliwym otwarciem się na kulturę i duchowość ich epoki, chrześcijaństwo pozostałoby prawdopodobnie mało ważną sektą na obrzeżach judaizmu i nigdy nie stałoby się duchowym i moralnym nurtem, który przemienił kulturowe oblicze Europy ${ }^{29}$.

28 J. Bagrowicz, Towarzyszyć wzrastaniu, s. 211.

29 T. Halík, Co nie jest chwiejne, jest nietrwate. Labiryntem świata z wiarq i watpliwościami, Kraków 2004, s. 69. 
Dialog - jak podkreśla M. Patalon - jest punktem wyjścia ewangelizacji, jej założeniem i niezbywalną postawą, nawrócenie zaś jest postrzegane jako wyzbycie się pychy i egoizmu, czyli partykularnego postrzegania rzeczywistości. Kościół przyswaja to, co we współczesnej kulturze jest z ducha Ewangelii. Nie może to oznaczać odejścia od nauki Chrystusa czy dogmatycznych kompromisów chrześcijaństwa, ale jest znakiem jego uniwersalności i katolickości ${ }^{30}$.

\section{Zakończenie}

Przełom XX i XXI wieku przyniósł wiele przemian, a zwłaszcza postępującą pluralizację życia, szczególnie pod względem społecznym, światopoglądowym i obyczajowym. Jesteśmy świadomi tego, że dokonujące się przemiany polityczne, społeczne i religijne w naszym kręgu kulturowym stawiają przed edukacją religijną szczególne zadania i wyzwania. Dokonujące się przemiany dotykają wszystkich ludzi, ale najbardziej jest na nie wrażliwe młode pokolenie. Okres dorastania zdaje się sprzyjać zjawisku ulegania wszystkim nowym trendom, i to nie tylko w zakresie mody, ale i życia moralno-religijnego. Dlatego też współczesne młode pokolenie jest postawione w obliczu szans rozwojowych dotąd niemal niespotykanych, ale też i w obliczu niebezpieczeństw i zagrożeń, od których wolne były poprzednie pokolenia. Stawia to szczególne wymogi przed tymi, którzy stają obok młodych po to, aby wspomagać ich w procesie dorastania, zwłaszcza kształtowania postawy religijno-moralnej.

W procesie edukacji szczególnie ważne wydaje się być kształtowanie postawy dialogu. Szczególną rolę może tu spełnić edukacja religijna młodych. Nauczanie religii i katecheza są bardzo istotnym i bardzo ważnym miejscem wychowania postawy i umiejętności dialogu z Bogiem i ludźmi. Najpierw są one właściwym środowiskiem kształtowania świadomości własnej tożsamości. Następnie, dostarczają wielu istotnych wiadomości z zakresu wiedzy o zróżnicowaniu kulturowym i religijnym, o potrzebie dialogu międzyreligijnego czy międzywyznaniowego. Coraz częstsze kontakty z wyznawcami innych religii czy wyznań religijnych stają się okazją do zdobywania umiejętności dialogu i współdziałania. Bardzo wiele zależy od przebiegu procesu nauczania i stosowanych metod w edukacji religijnej. Bardzo pomocna będzie aktywizacja uczniów w procesie nauczania, kształcenie umiejętności współpracy z innymi, nauka szacunku dla zdania innych, umiejętności szu-

${ }^{30}$ Por. M. Patalon, Pedagogika ekumenizmu. Procesualność jako paradygmat interkonfesyjnej i intereligjjnej heremenutyki w ujęciu Johna B. Cobba, Jr., Gdańsk 2007, s. 166. 
kania kompromisu i porozumienia. Z tym łączy się powierzanie młodym konkretnych zadań, związanych z ich obecnością w społeczności, także we wspólnocie Kościoła lokalnego.

\section{Dialogue in religious education (Summary)}

It isn't difficult to notice that contemporary society differs more and more not only in opinions on sociopolitical and cultural issues, but also in religious and denominational aspects. In this pluralistic world dialogue becomes more and more important as a way of communication between people and of making contact and co-operation for the good of the individual human person and society. The dialogue becomes therefore a basic way of building social community.

In the second half of the 20th. century began the dialogue between different religions. For over hundred years has continued the ecumenical dialogue between particular Christian denominations. A very important role in the preparation for the dialogue, especially ecumenical and inter-religious dialogue, is religious education: the teaching of different religions and upbringing to dialogical attitude in situations of meeting with people developed in other cultures, worldviews or religions.

Efficacy of religious education depends on education in families, schools and other educational communities. It depends on the positive influence of these communities in forming the dialogical attitude. A very important role in this process is religious education in schools as well as in youth religious groups and movements. Taking care of cultural and religious identity of young people shouldn't be any handicap in forming dialogical attitude and preparing for co-operation between different people. 